OPEN ACCESS

Edited by:

Claudio Mauro,

University of Birmingham,

United Kingdom

Reviewed by:

Massimiliano Ruscica

University of Milan, Italy

Stephanie W. Watts,

Michigan State University,

United States

*Correspondence:

Tomasz J. Guzik

tomasz.guzik@glasgow.ac.uk

Specialty section:

This article was submitted to

Inflammation,

a section of the journal

Frontiers in Immunology

Received: 29 March 2019

Accepted: 05 August 2019

Published: 04 September 2019

Citation:

Sagan A, Mikolajczyk TP,

Mrowiecki W, MacRitchie N, Daly K,

Meldrum A, Migliarino S, Delles C,

Urbanski K, Filip G, Kapelak B,

Maffia P, Touyz R and Guzik TJ (2019)

$T$ Cells Are Dominant Population in Human Abdominal Aortic Aneurysms and Their Infiltration in the Perivascular

Tissue Correlates With Disease

Severity. Front. Immunol. 10:1979.

doi: 10.3389/fimmu.2019.01979

\section{T Cells Are Dominant Population in Human Abdominal Aortic Aneurysms and Their Infiltration in the Perivascular Tissue Correlates With Disease Severity}

\author{
Agnieszka Sagan ${ }^{1,2}$, Tomasz P. Mikolajczyk ${ }^{2,3}$, Wojciech Mrowiecki ${ }^{4}$, Neil MacRitchie ${ }^{3}$, \\ Kevin Daly ${ }^{5}$, Alan Meldrum ${ }^{5}$, Serena Migliarino ${ }^{1}$, Christian Delles ${ }^{1}$, Karol Urbanski ${ }^{2}$, \\ Grzegorz Filip ${ }^{6}$, Boguslaw Kapelak ${ }^{6,7}$, Pasquale Maffia ${ }^{1,3,8}$, Rhian Touyz $^{1}$ and \\ Tomasz J. Guzik ${ }^{1,2 *}$ \\ ${ }^{1}$ BHF Cardiovascular Research Centre, Institute of Cardiovascular and Medical Sciences, University of Glasgow, Glasgow, \\ United Kingdom, ${ }^{2}$ Department of Internal and Agricultural Medicine, Jagiellonian University Medical College, Kraków, Poland, \\ ${ }^{3}$ Centre for Immunobiology, Institute of Infection, Immunity and Inflammation, University of Glasgow, Glasgow, \\ United Kingdom, ${ }^{4}$ Department of Vascular Surgery, CUMRiK, University Hospital, Kraków, Poland, ${ }^{5}$ Department of Vascular \\ Surgery, Queen Elizabeth University Hospital, Glasgow, United Kingdom, ${ }^{6}$ Department of Cardiovascular Surgery and \\ Transplantology, John Paul II Hospital, Kraków, Poland, ${ }^{7}$ Institute of Cardiology, Jagiellonian University Medical College, \\ Kraków, Poland, ${ }^{8}$ Department of Pharmacy, University of Naples Federico II, Naples, Italy
}

Abdominal Aortic Aneurysm (AAA) is a major cause of cardiovascular mortality. Adverse changes in vascular phenotype act in concert with chronic inflammation to promote AAA progression. Perivascular adipose tissue (PVAT) helps maintain vascular homeostasis but when inflamed and dysfunctional, can also promote vascular pathology. Previous studies suggested that PVAT may be an important site of vascular inflammation in AAA; however, a detailed assessment of leukocyte populations in human AAA, their anatomic location in the vessel wall and correlation to AAA size remain undefined. Accordingly, we performed in depth immunophenotyping of cells infiltrating the pathologically altered perivascular tissue (PVT) and vessel wall in AAA samples at the site of maximal dilatation $(n=51$ patients). Flow cytometry revealed that $T$ cells, rather than macrophages, are the major leukocyte subset in AAA and that their greatest accumulations occur in PVT. Both CD4 ${ }^{+}$ and $\mathrm{CD} 8^{+} \mathrm{T}$ cell populations are highly activated in both compartments, with $\mathrm{CD} 4^{+} \mathrm{T}^{-}$ cells displaying the highest activation status within the AAA wall. Finally, we observed a positive relationship between $T$ cell infiltration in PVT and AAA wall. Interestingly, only PVT T cell infiltration was strongly related to tertiles of AAA size. In summary, this study highlights an important role for PVT as a reservoir of T lymphocytes and potentially as a key site in modulating the underlying inflammation in AAA.

Keywords: abdominal aortic aneurysm, $\mathrm{T}$ cell, perivascular adipose tissue, inflammation, macrophages 


\section{INTRODUCTION}

Abdominal aortic aneurysm (AAA) is defined as a pathological dilatation of the aorta, to more than 1.5 times the normal diameter. AAAs are one of the most important causes of cardiovascular morbidity and mortality and occurs in up to $9 \%$ of men after 65 years of age (1). AAA shares many of the same risk factors as atherosclerosis including advanced age, smoking, hypertension, and hypercholesterolemia (2). Recently, it has also been shown that elevated BMI also increased the likelihood of AAA diagnosis (3). The mechanisms of AAA, defined primarily in animal model studies, are complex, involving smooth muscle cell apoptosis, oxidative stress (4), and inflammation (5). Clinically, patients with AAA have elevated circulating pro-inflammatory cytokines (6-8) and immunohistochemical studies of AAA reveal the presence of inflammatory cells such as macrophages, T cells, B cells, dendritic cells, natural killer cells, neutrophils, and mast cells (9-14).

Amongst inflammatory cells, macrophages are an important subpopulation with their role in the pathogenesis of AAA welldescribed in both mice and humans (15-21). Furthermore, $\mathrm{T}$ and $\mathrm{B}$ cell numbers are increased in cryosections of aneurysmal tissues $(13,22)$ with lymphocyte density negatively correlating with collagen and elastin content indicating a contribution of adaptive immune cells to AAA instability (14). Both Th1 (2325) and Th2 (26) $\mathrm{CD} 4^{+} \mathrm{T}$ cells as well as $\mathrm{CD} 8^{+} \mathrm{T}$ cells have been implicated in promoting AAA formation $(23,27,28)$. Despite the evidence of the presence of these cells in aneurysmatic vascular wall $(23,26-30)$, less is known regarding their respective number, activation status and spatial distribution within the vessel wall. While circulating pro-inflammatory $\mathrm{CD} 4^{+} \mathrm{T}$ cells are increased in patients with moderate sized AAA (24), it is uncertain if there is a relationship between aortic wall $\mathrm{T}$ cell content and AAA size.

While most studies focus on alterations in the vascular wall of AAA, recent interest in the role of perivascular adipose tissue (PVAT) inflammation and its clinical significance (31-33) raise an important question on the role of perivascular tissue (PVT) in AAA. PVT regulates vascular function; however, imbalances between the production and release of protective factors and proinflammatory molecules in PVT may result in vascular pathology $(34,35)$. In various cardiovascular and metabolic diseases such as atherosclerosis, hypertension, diabetes, or obesity, dysfunctional PVT plays a critical role, characterized by oxidative stress and inflammation $(32,36,37)$. Furthermore, gene expression analysis suggested increased infiltration of immune cells into PVT surrounding AAA (38). Therefore, it is essential to characterize immune cell subpopulations infiltrating PVT surrounding AAAs and address their potential functional implications for aneurysm progression and size.

Here, we utilized a pool of clinical AAA samples to perform a quantitative assessment of leukocyte subsets, of which $\mathrm{T}$ cells are most abundant. We also focused on their presence in PVT, aiming to understand their links to AAA wall infiltration as well as the relationship to AAA size.

\section{METHODS}

\section{Human Samples}

Segments of AAA were obtained during AAA repair surgery at the site of maximal dilatation from 51 patients. Clinical data including major risk factors for atherosclerosis and AAA were recorded at the time of surgery (Table 1 ). Hypercholesterolemia was defined as a plasma TC $>4.8 \mathrm{mM}$ or the use of cholesterol lowering medication. Patients were considered hypertensive if BP was $>140 / 90 \mathrm{mmHg}$ or if patients were currently taking BP lowering medication. Diabetes was diagnosed based on a fasting glucose $>5.5 \mathrm{mM}$ or current treatment with insulin or oral hypoglycaemic agent (39).

AAA size was determined in pre-operative CT and verified intraoperatively. Immediately after harvesting, samples were placed in ice-cold $\left(4^{\circ} \mathrm{C}\right)$ phosphate buffered saline (PBS, Gibco, Invitrogen, Carlsbad, CA, USA) and transported to the laboratory. Written informed consent was obtained from all patients. Collection of tissue was approved by the local Research Ethics Committee of the Jagiellonian University, Kraków, Poland (Approval No. KBET/78/B/2012) and the West of Scotland Research Ethics Service Committee for the Biorepository at the Queen Elizabeth Hospital, Glasgow, United Kingdom (Approval No. 10/S/0704/60). Importantly, due to amount of tissue available and cell numbers in $\mathrm{CD} 45^{+}$gate, not all measurements were

TABLE 1 | Patient clinical parameters including risk factors and current treatment regimens recorded at the time of surgery.

\begin{tabular}{|c|c|}
\hline$N$ & 51 \\
\hline Age (years, mean \pm SD) & $67.9 \pm 8$ \\
\hline Sex (M:F) & $42: 9$ \\
\hline Present thrombus ( $n, \%)$ & $44(86 \%)$ \\
\hline Aneurysms diameter ( $\mathrm{mm}$, mean $\pm \mathrm{SD}$ ) & $62 \pm 14$ \\
\hline \multicolumn{2}{|l|}{ RISK FACTORS } \\
\hline Smoking $(n, \%)$ & $36(70 \%)$ \\
\hline Hypertension ( $n, \%)$ & 40 (78\%) \\
\hline Systolic BP (mmHg, mean \pm SD) & $129.3 \pm 15$ \\
\hline Diastolic BP (mmHg, mean \pm SD) & $79.1 \pm 7.9$ \\
\hline Hypercholesterolemia ( $n, \%)$ & 47 (92\%) \\
\hline Total Cholesterol (mmol/L, mean \pm SD) & $4.9 \pm 1.27$ \\
\hline Overweight/Obesity $(n, \%)$ & $31(61 \%)$ \\
\hline $\mathrm{BMl}\left(\mathrm{kg} / \mathrm{m}^{2}\right.$, mean $\left.\pm \mathrm{SD}\right)$ & $26.25 \pm 3.7$ \\
\hline Diabetes (T2) (n, \%) & $7(14 \%)$ \\
\hline \multicolumn{2}{|l|}{ MAIN MEDICATIONS } \\
\hline Diuretics $(n, \%)$ & $20(39 \%)$ \\
\hline ACE inhibitors/ARB (n, \%) & $32(63 \%)$ \\
\hline ASA $(n, \%)$ & 38 (74\%) \\
\hline Other antithrombotic $(n, \%)$ & $7(14 \%)$ \\
\hline$\beta$ blockers $(n, \%)$ & $26(51 \%)$ \\
\hline Calcium antagonist $(n, \%)$ & $8(16 \%)$ \\
\hline HMG CoA Inhibitors (n, \%) & $43(89 \%)$ \\
\hline
\end{tabular}

ASA, acetylsalicylic acid; BMI, body mass index; ACE, Angiotensin Converting Enzyme; HMG COA Inhibitor, hydroxy-3-methyl-glutaryl-CoA reductase inhibitor. 
possible in all subjects and $n$ numbers are provided in individual figure legends.

\section{Flow Cytometry Analysis of Cells in Tissues}

In the laboratory, fragment of aneurysm was divided into two parts: wall (containing mostly intima-media) and PVT (containing PVAT and contiguous remodeled adventitia). Samples, were subsequently mechanically disrupted and digested with a cocktail of enzymes containing $125 \mathrm{U} / \mathrm{ml}$ collagenase type $\mathrm{XI}, 60 \mathrm{U} / \mathrm{ml}$ hyaluronidase type IVS and $450 \mathrm{U} / \mathrm{ml}$ collagenase type I (all from Sigma-Aldrich, Irvine, UK) in PBS with calciummagnesium containing $20 \mathrm{mM}$ Hepes at $37^{\circ} \mathrm{C}$ for $20 \mathrm{~min}$ with gentle agitation to isolate residual cells infiltrating tissues. The resulting cell suspension was then passed through a $70 \mu \mathrm{m}$ strainer (BD Pharmingen, San Diego, CA, USA). Cells were incubated with fluorescently labeled antibodies for $20 \mathrm{~min}$ at $4^{\circ} \mathrm{C}$ (for details see Supplemental Table 1). Fluorescence Minus One (FMO) was used as negative control. After washing, cells were re-suspended in PBS with $1 \%$ fetal bovine serum (FBS) (Gibco, ThermoFisher Scientific, UK) and data acquired on a FACSCanto II cytometer (BD Bioscience, UK) and analyzed using FACSDiva ${ }^{\mathrm{TM}}$ and FlowJo software (Tree Star Inc, Olten, Switzerland).

\section{Immunofluorescence Staining}

Immunofluorescence was performed on frozen $7 \mu \mathrm{m}$ OCTembedded aneurysmal tissue sections. For $\mathrm{T}$ cell visualization, rabbit polyclonal anti-human CD3 (ab5690; Abcam, Cambridge, UK) was employed and for macrophages, mouse monoclonal anti-human CD68 (ab955; Abcam, Cambridge, UK) was used. Appropriate secondary antibodies were employed (Donkey antirabbit IgG-Alexa Fluor 594 and Donkey anti-mouse IgGAlexa Fluor 647, ThermoFisher Scientific). Sections treated with secondary antibodies alone did not show specific staining. Staining was visualized on a Zeiss Cell Observer SD confocal microscope (Zeiss, Oberkochen, Germany).

\section{Statistical Analysis}

Patient clinical parameters are expressed as Mean \pm SD as detailed in Table 1. Other data are expressed as Mean \pm SEM except on dot plot graphs where data is expressed as Median (Q1;Q3). To test normality of distribution, Kolmogorov-Smirnov test was employed. Comparison between related samples were made using Wilcoxon matched pairs test, one-way ANOVA or $t$-test and between independent samples using Mann-Whitney test. Correlation between cells was assessed by Spearman's rank correlation analysis.

\section{RESULTS}

\section{Local Inflammation in Aneurysm Is Prone to Perivascular Tissue}

We performed flow cytometry on cell suspensions to characterize leukocyte content and its subsets. The gating strategy used in these studies is presented in Figure 1A. We observed that following tissue digestion, absolute cell counts revealed a greater cellularity to the PVT layer in comparison with
AAA wall (Supplemental Figure 1). Interestingly, analysis of the percentage distribution of leukocyte subpopulations in AAA shows that the major subpopulation are $\mathrm{T}$ cells for both aneurysmal PVT $(29 \pm 3 \%)$ and wall $(31 \pm 3 \%$; Figure 1B) while other leukocyte subsets were less abundant, with a surprisingly low presence of macrophages in both AAA wall and PVT (Figure 1B). Immunofluorescence staining of AAA revealed an increased presence of $\mathrm{T}$ cells within PVT compared with AAA wall (Figure 1C). Interestingly, T cells and macrophages could also on occasion be found co-localizing within the PVT (Figure 1C). Quantifiable results obtained by flow cytometry revealed that the majority of leukocytes localized within aneurysmal PVT. Median (Q1;Q3) values for wall vs. PVT were, respectively, $578(293 ; 1353)$ vs. 1,428 (434;3137) cells/mg tissue (Figures 2A,B).

\section{T Cell Infiltration in AAA Perivascular Tissue}

As $\mathrm{T}$ cells were the most abundant leukocyte subpopulation, we investigated them in more detail by showing that the $\mathrm{T}$ cell content in aneurysmal PVT was significantly higher in comparison to aneurysmal wall. Median (Q1;Q3) values were $109(38 ; 351)$ vs. $346(69 ; 862)$ cells/mg for wall and PVT, respectively (Figures $\mathbf{2 A , C}$ ). In spite of these differences, we found a positive correlation between total leukocyte content in PVT and AAA wall $R=0.38, p=0.015$ (Figure 2F). A similar correlation was observed for $\mathrm{T}$ cell content $R=0.42, p=0.007$ (Figure 2G).

With regards to $\mathrm{T}$ cell subtypes, $\mathrm{CD}^{+} \mathrm{T}$ cells were significantly increased in PVT: $187(41 ; 580)$ cells/mg compared with wall 81 (20;226) cells/mg (Figure 2D). While a trend toward increased $\mathrm{CD}^{+}{ }^{+} \mathrm{T}$ cells was observed in aneurysmal PVT, this did not reach significance (Figure 2E).

Although over $80 \%$ of our patient samples derived from males, we were curious if we could observe any gender differences in total leukocyte or $\mathrm{T}$ cell counts within patient samples. Interestingly, female patients displayed significantly more leukocytes and T cells within the PVT in comparison to male patients (Figures 3A,B).

\section{Activated and Immunosenescent T Cells in AAA}

Next, we investigated the activation status of aneurysmal $\mathrm{T}$ cells by utilizing the activation markers: CD69, CD25, HLADR as well as CCR5 and the absence of CD28 (CD28 $8^{\text {null; }}$ representing immunosenescent phenotype). We revealed that $\mathrm{CD} 4^{+} \mathrm{T}$ cells are preferentially activated within the aneurysmal wall (Supplemental Table 2A). More than 50\% of $\mathrm{T}$ cells expressed the early activation marker CD69 in AAA, either in PVT or in wall; with a higher percentage of $\mathrm{CD} 4^{+} \mathrm{CD} 69^{+}$cells in aneurysmal wall. This was in line with higher percentages of $\mathrm{CD}^{+} \mathrm{T}$ cells expressing the late activation marker HLA-DR in AAA wall than in aneurysmal PVT (Supplemental Table 2A). Interestingly, while CD8 cells within both AAA wall and PVT were highly activated, they did not differ between wall and 

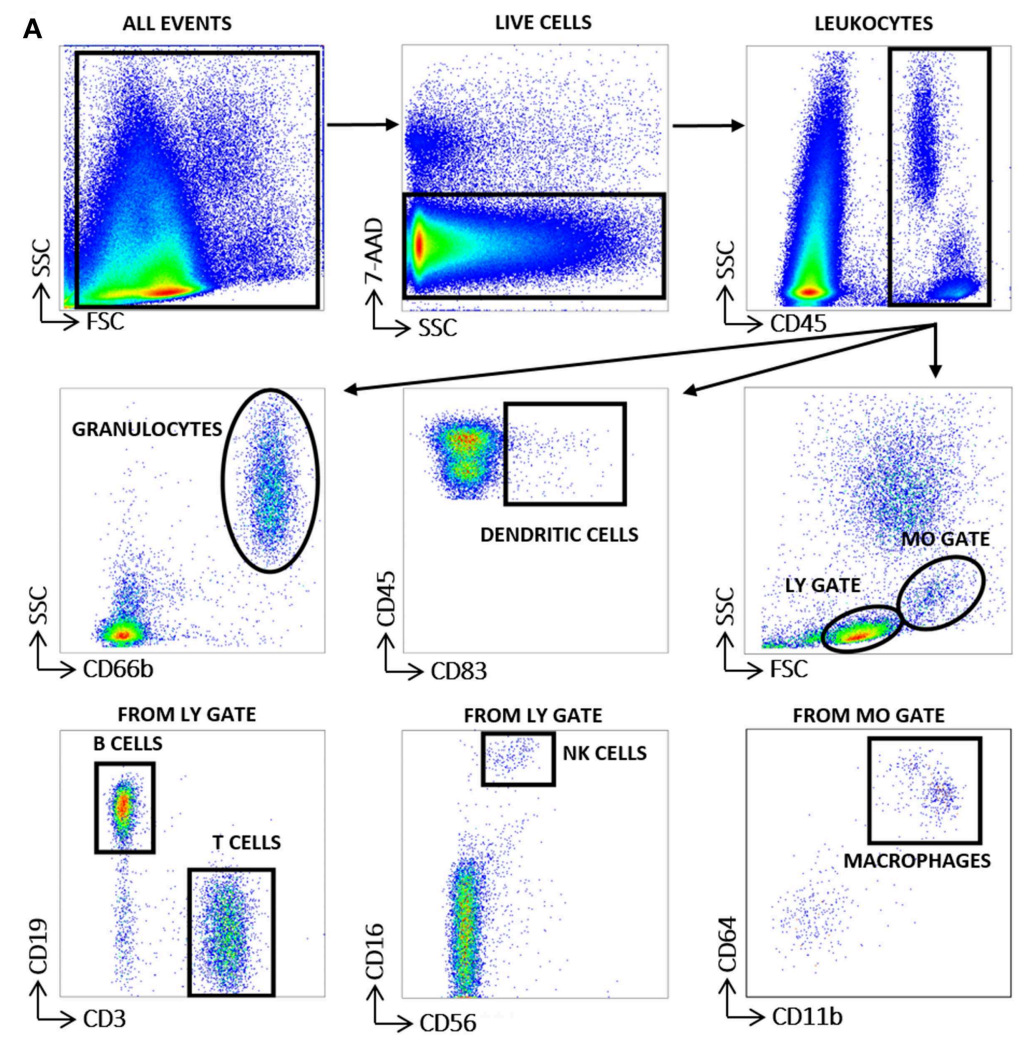

B

WALL AAA

PVT AAA
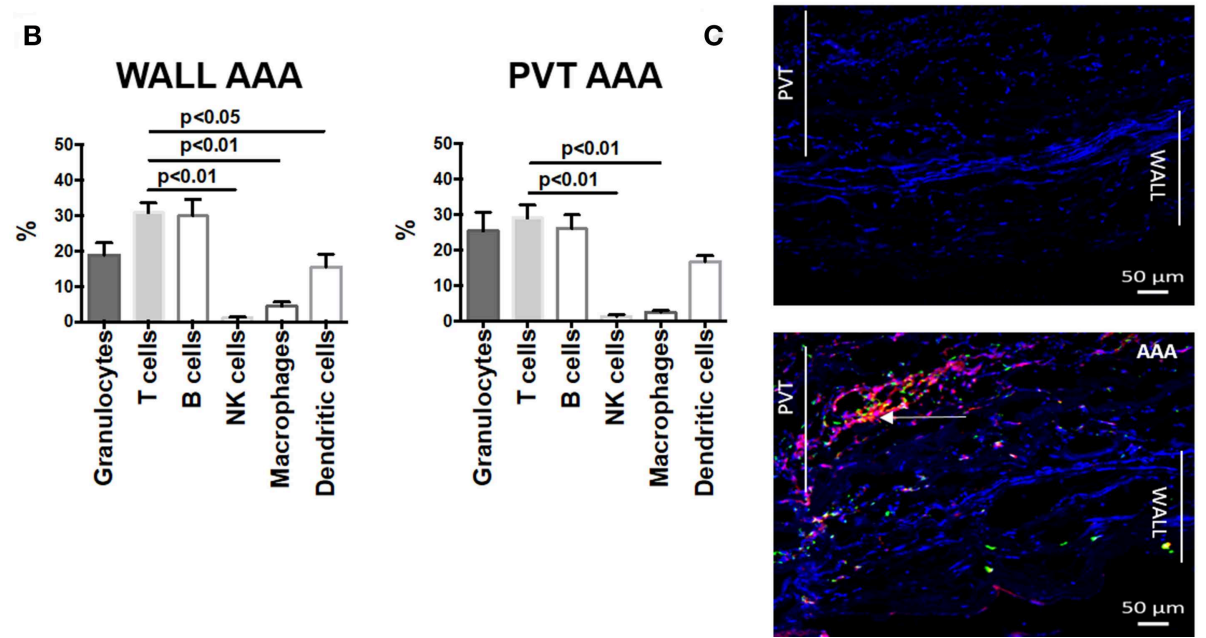

FIGURE 1 | Aortic abdominal aneurysm (AAA) leukocyte infiltration: comparison and relationship between aneurysmal wall and PVT. (A) Gating strategy depicting identification of total leukocytes $\left(\mathrm{CD} 45^{+}\right)$and leukocyte sub-populations: granulocytes, dendritic cells, B cells, T cells, NK cells and macrophages in AAA (aortic

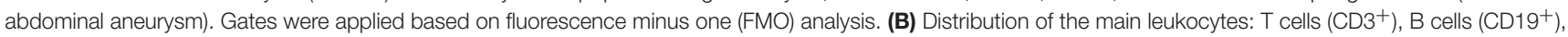
NK cells $\left(\mathrm{CD} 16^{+} \mathrm{CD}^{+} 6^{+}\right)$, macrophages $\left(\mathrm{CD} 11 \mathrm{~b}^{+} \mathrm{CD}^{+} 4^{+}\right)$, dendritic cells $\left(\mathrm{CD} 83^{+}\right)$, granulocytes $\left(\mathrm{CD} 6 \mathrm{~b}^{+}\right)$in wall and PVT of AAA tissue $(n=8-11)$, T cell percentages compared to other leukocyte subpopulations, $t$-test for related samples, $p$ values presented on graphs only for statistically significant comparisons. (C) Bottom panel: example of immunofluorescence staining of T cells $\left(\mathrm{CD}^{+}\right)$shown in red and macrophages $\left(\mathrm{CD}^{+} 8^{+}\right)$shown in green in PVT and wall of an AAA. Nuclear staining (DAPI) is shown in blue. Example of T cell and macrophage co-localization shown by yellow/orange staining; white arrow. Representative of $n=5$; Top panel: negative control consisting of secondary antibody staining only with DAPI. Scale bar $=50 \mu \mathrm{M}$. 
A
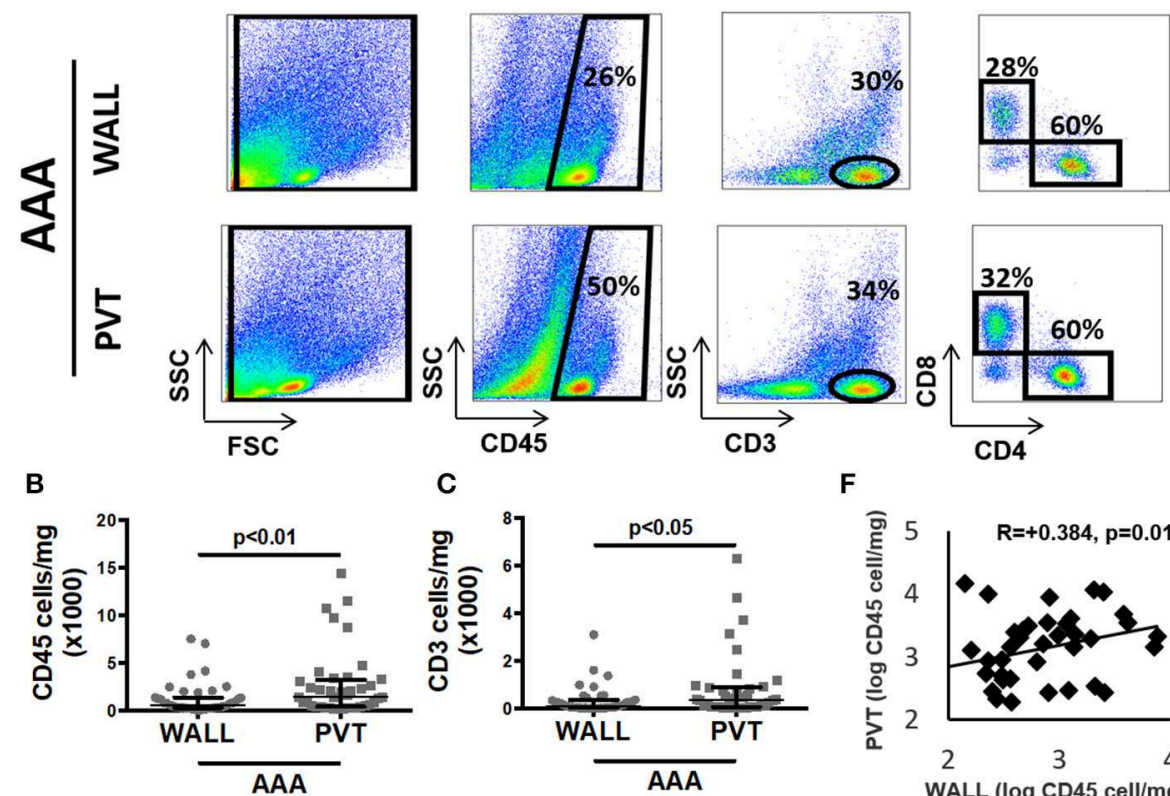

C

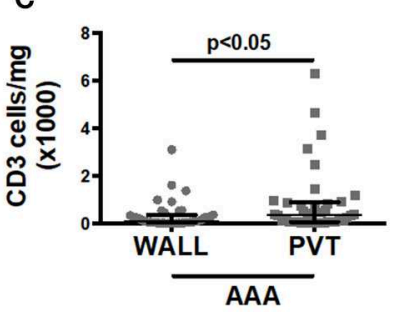

$\mathbf{F}$

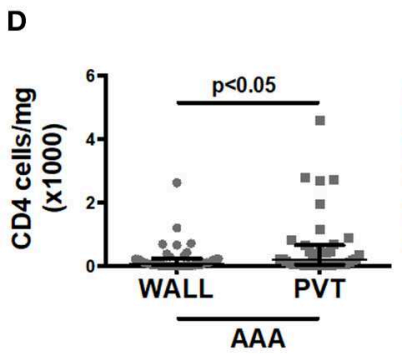

E

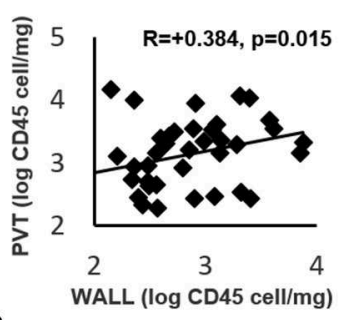

G
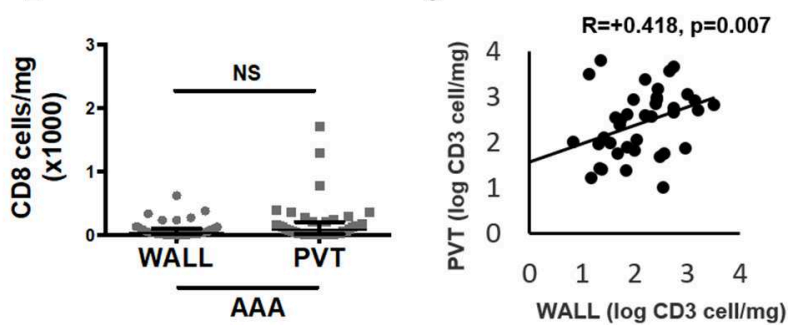

FIGURE 2 | Aortic abdominal aneurysm (AAA) leukocyte infiltrate: comparison and relationship between aneurysmal wall and PVT. (A) Example of flow cytometric identification of leukocytes $\left(\mathrm{CD} 45^{+}\right)$, total T cells $\left(\mathrm{CD}^{+}\right)$and $\mathrm{CD}^{+}, \mathrm{CD}^{+} \mathrm{T}$ cell subpopulations in aneurysmal wall and PVT. (B) Leukocyte number per mg of aneurysmal wall vs. PVT, $n=40,{ }^{* *} p<0.01$ (Wilcoxon matched paired). (C) T cells number per mg of aneurysmal wall vs. PVT, $n=39,{ }^{*} p<0.05$ (Wilcoxon matched paired). (F) Spearman rho correlation between number of leukocytes in aneurysmal wall and PVT; $R=0.384, n=40, p=0.015$. (G) Spearman rho correlation between number of T cells in aneurysmal wall and PVT; $R=0.418, n=39, p=0.007$. (D) CD4 ${ }^{+}$T cell number per mg of wall and PVT of AAA tissue, $n=39$, $p<0.05$ (Wilcoxon matched paired). (E) CD8 ${ }^{+}$T cell number per mg of wall and PVT in AAA, $n=39$, NS (Wilcoxon matched paired).
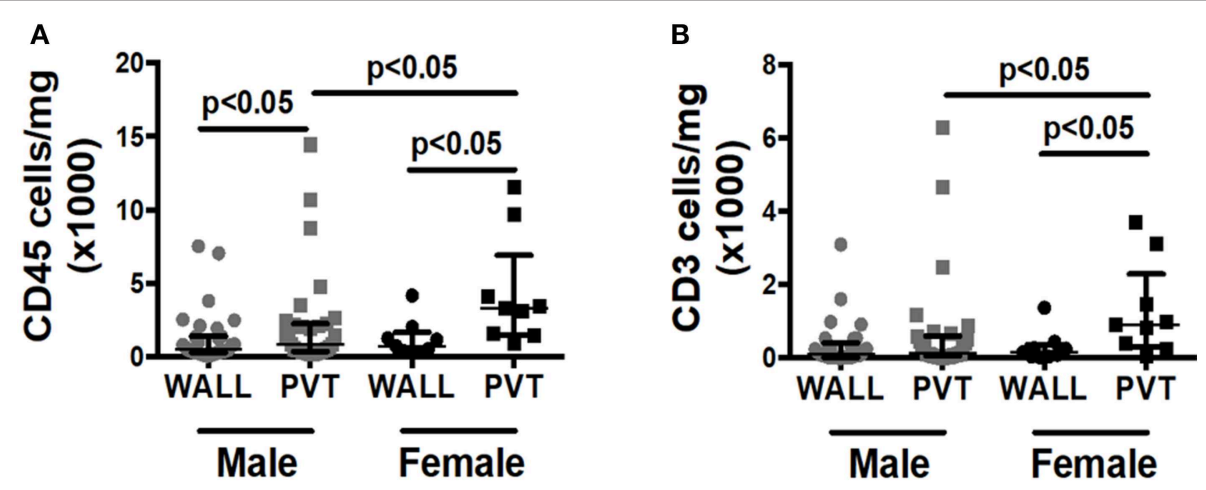

FIGURE 3 | Effect of patient gender on immune cell numbers in AAA wall and PVT. Male vs. female total leukocyte and T cell content in AAA PVT and wall. (A) Leukocyte number per mg of aneurysmal wall and PVT in male group $n=31$ vs. female group $n=9$ (B). T cell number per mg of aneurysmal wall and PVT in male group $n=30$ vs. female group $n=9$. Mann-Whitney test for comparison male vs. female for wall and PVT, Wilcoxon test for comparison wall vs. PVT within male and female group. $p$ values presented on graphs only for statistically significant comparisons. 
PVT (Supplemental Table 2B). Similar to markers of activation, there was an increased presence of $\mathrm{CD} 4{ }^{+} \mathrm{CCR} 5^{+}$cells in aneurysmal wall compared with PVT, which was not observed in the $\mathrm{CD} 8^{+} \mathrm{T}$ cell population, although notably CCR5 was present on over $40 \%$ of all CD8 cells present either in AAA wall or PVT (Supplemental Table 2B).

In contrast to the above, the percentages of immunosenescent, dysregulated $\mathrm{CD} 8^{+} \mathrm{CD} 28^{\text {null }} \mathrm{T}$ cells were higher in AAA wall than in PVT whereas $\mathrm{CD} 4^{+} \mathrm{CD} 28^{\text {null }}$ cells did not differ between aneurysmal PVT and wall (Supplemental Tables 2A,B).

\section{T Cell Infiltration and AAA Size}

Finally, to ascertain if $\mathrm{T}$ cell infiltration is associated with AAA stage/severity, we stratified $\mathrm{T}$ cell content in both wall and PVT according to AAA diameter (Figure 4). While no significant differences in $\mathrm{T}$ cell content were observed in AAA wall, significant differences in T cell content were seen in PVT with the highest tertile containing the greatest number of $\mathrm{T}$ cells while the lowest tertile had PVT T cell numbers comparable with wall.
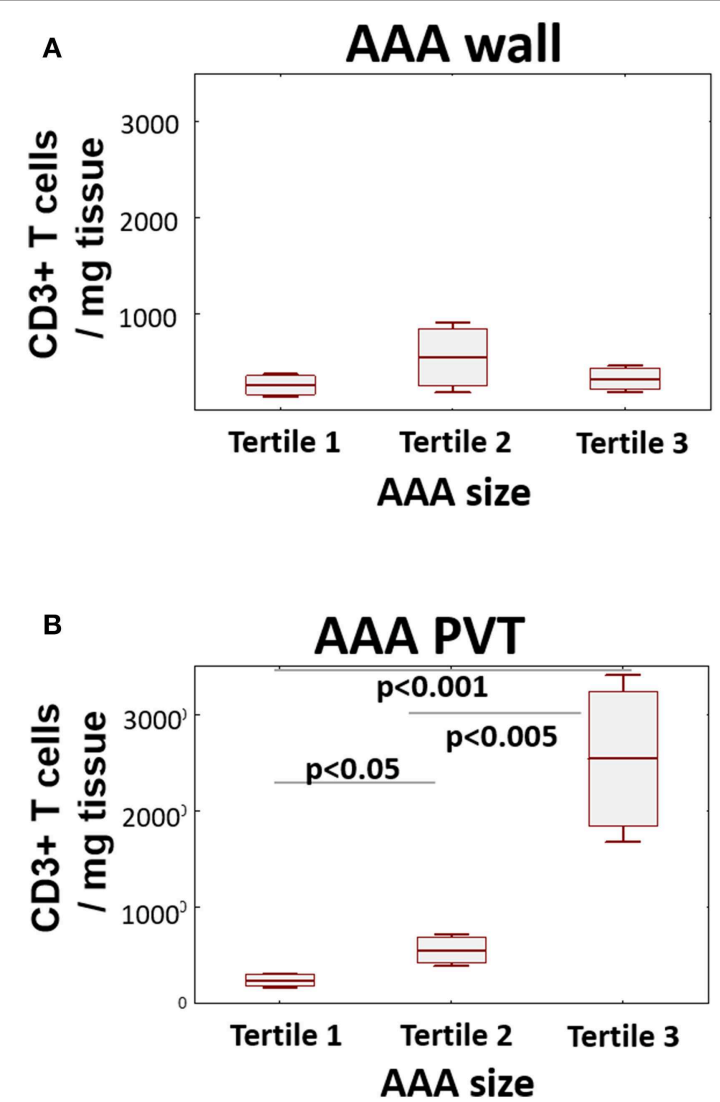

FIGURE 4 | Relationship between T cell number and AAA size. AAA diameter was determined by preoperative CT. Graphs display relationship between AAA size (tertile $1 \leq 53 \mathrm{~mm}$; tertile $2 \leq 60 \mathrm{~mm}$; tertile $3>60 \mathrm{~mm}$ ) and $\mathrm{CD}^{+}{ }^{+}$cell infiltration in wall (A) and PVT (B) (mean/SEM/25-75 Cl); $(n=20 / 10 / 9$ for tertiles); statistical comparisons were performed by ANOVA with Neuman-Keuls post-hoc analysis.

\section{DISCUSSION}

In this investigation, we provide novel quantitative data on leukocyte populations in late-stage AAA, which identified $\mathrm{T}$ cells as the dominant immune cell population in these vessels. Moreover, we identified that PVT is a key site of $\mathrm{T}$ cell accumulation in AAA with $\mathrm{T}$ cell numbers increasing with AAA size, with these conclusions based on analysis of a large cohort of AAA samples. This suggests that the pro-inflammatory role of PVT in the development of vascular pathology (40-43) can now be extended to late-stage AAAs.

Our study provides an important quantitative assessment and clinical context to previous immunohistochemical and gene expression reports indicating a potentially important role for the abnormal necrotic, inflamed, proteolytic tissue adjacent to the aneurysmal wall in regulating ongoing vascular damage. Indeed, inflammatory cells such as neutrophils, T cells and others often surround necrotic adipocytes (38). The role of $\mathrm{T}$ cells in this process remains unclear. Using detailed, quantitative flow cytometry studies, we have demonstrated that the AAA T cell population expresses characteristic activation markers. While there are significantly more leukocytes and $\mathrm{T}$ cells in the PVT, cells in the pathologically damaged AAA wall are more activated (especially $\mathrm{CD}^{+}$cells) or represent dysregulated, immunosenescent $\mathrm{CD} 28^{\text {null }}$ phenotype (particularly $\mathrm{CD}^{+}$cells). This is interesting, as we have recently shown that $\mathrm{CD} 8^{+} \mathrm{CD} 28^{\text {null }} \mathrm{CD} 57^{+}$cells are important in the immediate response to vascular injury (44). These cells are known to produce increased amounts of proinflammatory TNF- $\alpha$ and IFN- $\gamma$ further contributing to vascular inflammation. Therefore, this population may be important in AAA pathology with percentages of peripheral blood $\mathrm{CD} 8^{+} \mathrm{CD} 28^{\text {null }}$ cells being higher in AAA patients than controls but without a clear relationship to the maximal aneurysm diameter (24).

In spite of these differences, we observed a positive correlation between the numbers of both total $\mathrm{CD} 45^{+}$leukocytes and in particular $\mathrm{T}$ cells between PVT and AAA wall. This may be particularly relevant in the context of the debate regarding the source and trafficking of leukocytes to AAAs. Considering this, abluminal white thrombus which is located directly on the internal surface of the AAA wall, shows negligible numbers of leukocytes (45). The data we present here show an abundance of leukocytes in PVT which may suggest that trafficking of immune cells into the AAA wall may be secondary to their entry into the PVT, possibly via entry through PVAT associated postcapillary venules (38). Further support for PVAT recruitment of $\mathrm{T}$ cells came from the discovery that human adipocytes in PVAT surrounding atherosclerotic arteries produce chemoattractants and are able to induce chemotaxis of leukocytes including $\mathrm{T}$ cells (46). T cells are also found densely aggregated within the PVT in an angiotensin induced mouse model of hypertension (47) suggesting an "outside-in" infiltration into the vessel. However, in AAA samples, which contain adventitial neoangiogenesis, it may also be the case that $\mathrm{T}$ cells are recruited via the adventitial microvasculature, depending on the local cellular and cytokine environment. We used both flow cytometry 
and IHC to compare content and localization, respectively, for both macrophages and T cells in PVT and wall. T cells comprised a significantly greater proportion of leukocytes in both compartments with $\mathrm{T}$ cell numbers being highest of all in PVT. IHC analysis also revealed dense $\mathrm{T}$ cell staining within the PVT. This is somewhat expected considering this is the location where lymphocyte aggregates develop in AAA patients (48).

Previously, it was suggested that $\mathrm{CD} 4^{+} \mathrm{T}$ cells may play a crucial role in AAA formation in both animal models of disease and human pathology $(12,23,30)$. Our study supports this view, by demonstrating that $\mathrm{CD}^{+}{ }^{+} \mathrm{T}$ cells are the major $\mathrm{T}$ cell subtype in AAA. Despite leukocytes, including T cells, being constitutively present in healthy aorta (49), infiltration of Th1 $\mathrm{CD}_{4}^{+} \mathrm{T}$ cells from the adventitia into the media can distinguish thoracic aneurysmal aorta segments from nonaneurysmal dilated aorta (25). Our data now suggest that infiltrating cells are preferentially recruited to the PVT, where they are densely dispersed throughout the tissue layer, often in close proximity to less abundant PVT macrophages. While the results of such interactions are unclear in our samples, activated $\mathrm{T}$ cells have been shown to promote the release of macrophage derived pro-inflammatory factors in mouse models of AAA (30). Activated $\mathrm{CD}^{+}$Th1 cells are the dominant $\mathrm{T}$ cell in atherosclerotic murine aorta and have previously been shown to predominate in human AAA samples (23). Our data now indicates that PVT is a major reservoir of these cells. We also expand on these earlier findings by demonstrating that the majority of $\mathrm{CD}^{+}$and $\mathrm{CD} 8^{+} \mathrm{T}$ cells present within the aneurysm positively express CD69 as well as showing expression of other activation markers including HLA-DR ${ }^{+}$ and CCR5.

Elevated expression of CCR5 in PVT containing CD4 ${ }^{+}$ and $\mathrm{CD}^{+}$cells as well as a differential expression of these cells between AAA wall and PVT (seen for $\mathrm{CD}^{+} \mathrm{T}$ cells) provides a hint for the role of RANTES chemokine in $\mathrm{T}$ cell recruitment to PVT and AAA wall. This data, coupled with the fact that RANTES is upregulated within the adventitia of human AAA (8) may suggest a role for this chemokine in the regulation of $\mathrm{T}$ cell trafficking in AAA, which has been demonstrated in relation to many other risk factors of AAA such as hypertension (50). Furthermore, angiotensin II induced expression of RANTES within the vasculature and CCR5 on $\mathrm{T}$ cells is thought to mediate $\mathrm{T}$ cell accumulation within the PVAT and adventitia in a mouse model of hypertension (47) indicating the importance of this chemotactic axis in both mice and humans.

While the focus of our investigation was not $\mathrm{T}$ regulatory cells (Tregs), the relatively low frequency of CD25 expressed by both $\mathrm{CD} 4^{+}$and $\mathrm{CD} 8^{+} \mathrm{T}$ cells suggest Tregs were not abundant within either AAA wall or PVT. A protective role for Tregs has been demonstrated in animal models of AAA $(51,52)$ and loss of Tregs correlate with AAA severity (53). It can be envisaged that a shift in $\mathrm{T}$ cell subset balance occurs during the chronic inflammation associated with AAA resulting in a loss of $\mathrm{T}$ regulatory function with concomitant enhancement of pro-inflammatory $\mathrm{CD} 4^{+} \mathrm{Th} 1$ and Th17 cells (54).
We established a relationship between $\mathrm{T}$ cell number and AAA size for PVT but not for AAA wall indicating that PVT recruits (and/or retains) more $\mathrm{T}$ cells as AAA progresses in severity. The fact that $\mathrm{T}$ cells are more activated within the wall may suggest greater retention of highly activated cells within the wall compared with PVT or additional inflammatory cues are present that promotes activation of $\mathrm{T}$ cells locally. While the precise triggers and role for $\mathrm{T}$ cell mediated immune responses in human AAA remain unclear, the presence of $\mathrm{T}$ and $\mathrm{B}$ cell aggregates within AAA (or more complex artery tertiary lymphoid organs; ATLOs) are suggestive of an autoreactive immune response to unidentified self/modified self-antigens $(18,55)$. Local clonal expansion of $\mathrm{T}$ cells within AAA remains a matter of debate. While the function of ATLOs in human AAA remains unclear, they are closely linked to adaptive immune activation and may feasibly occur as a progression of earlier aberrant autoreactive immune responses resulting in a highly compartmentalized local immune response (56).

It is important to emphasize that we have studied advanced AAA disease. With increasing use of endovascular aortic repair only more advanced cases are undergoing an open operative repair. This may be a source of selection bias we should take into account when interpreting these results.

In summary, we demonstrate that the majority of immune cells in late-stage human AAA are present within the PVTs with a predominating presence of $\mathrm{T}$ cells. Activation of $\mathrm{T}$ cells is apparent within PVT with activation status increasing still further in AAA wall populations. We also provide evidence that $T$ cell content in PVT is enhanced with increasing maximal AAA dilatation, highlighting a potential important role for PVT inflammation in AAA pathology.

\section{DATA AVAILABILITY}

The datasets generated for this study are available on request to the corresponding author.

\section{ETHICS STATEMENT}

Written informed consent was obtained from all patients. Collection of tissue was approved by the local Research Ethics Committee of the Jagiellonian University, Kraków, Poland (Approval No. KBET/78/B/2012) and the West of Scotland Research Ethics Service Committee for the Biorepository at the Queen Elizabeth Hospital, Glasgow, United Kingdom (Approval No. $10 / S / 0704 / 60)$.

\section{AUTHOR CONTRIBUTIONS}

AS and TM designed and performed the experiments and wrote the manuscript. $\mathrm{WM}, \mathrm{KD}$, and $\mathrm{AM}$ designed clinical part of the study and obtained the clinical samples. CD participated in the sample collection. NM analyzed the data and wrote the manuscript. SM performed flow cytometric analysis and analyzed immunofluorescence. KU developed the methodology, performed the experiments, and analyzed the data. $\mathrm{KD}, \mathrm{AM}$, 
GF, and BK performed the clinical part of experiments. PM interpreted the data and wrote the manuscript. RT designed the experiments and provided comments on the manuscript. TG designed the experiments, obtained the clinical data, and wrote the manuscript. All authors have read and approved the final manuscript.

\section{FUNDING}

This study was supported by Mobility Plus Program of Polish Ministry of Science and Higher Education (1079/MOB/2013/0

\section{REFERENCES}

1. Dua A, Kuy S, Lee CJ, Upchurch GR Jr, Desai SS. Epidemiology of aortic aneurysm repair in the United States from 2000 to 2010. J Vasc Surg. (2014) 59:1512-7. doi: 10.1016/j.jvs.2014.01.007

2. Kent KC, Zwolak RM, Egorova NN, Riles TS, Manganaro A, Moskowitz AJ, et al. Analysis of risk factors for abdominal aortic aneurysm in a cohort of more than 3 million individuals. J Vasc Surg. (2010) 52:539-48. doi: $10.1016 /$ j.jvs.2010.05.090

3. Wang L, Djousse L, Song Y, Akinkuolie AO, Matsumoto C, Manson JE, et al. Associations of diabetes and obesity with risk of abdominal aortic aneurysm in men. J Obes. (2017) 2017:3521649. doi: 10.1155/2017/35 21649

4. Guzik B, Sagan A, Ludew D, Mrowiecki W, Chwala M, Bujak-Gizycka B, et al. Mechanisms of oxidative stress in human aortic aneurysms-association with clinical risk factors for atherosclerosis and disease severity. Int J Cardiol. (2013) 168:2389-96. doi: 10.1016/j.ijcard.2013.01.278

5. Weintraub NL. Understanding abdominal aortic aneurysm. $N$ Engl J Med. (2009) 361:1114-6. doi: 10.1056/NEJMcibr0905244

6. Hellenthal FA, Pulinx B, Welten RJ, Teijink JA, van Dieijen-Visser MP, Wodzig WK, et al. Circulating biomarkers and abdominal aortic aneurysm size. J Surg Res. (2012) 176:672-8. doi: 10.1016/j.jss.2011.09.040

7. Lindeman JH, Abdul-Hussien H, Schaapherder AF, Van Bockel JH, Von der Thusen JH, Roelen DL, et al. Enhanced expression and activation of pro-inflammatory transcription factors distinguish aneurysmal from atherosclerotic aorta: IL-6- and IL-8-dominated inflammatory responses prevail in the human aneurysm. Clin Sci. (2008) 114:687-97. doi: $10.1042 / C S 20070352$

8. Jones GT, Phillips LV, Williams MJ, van Rij AM, Kabir TD. Two C-C family chemokines, eotaxin and RANTES, are novel independent plasma biomarkers for abdominal aortic aneurysm. J Am Heart Assoc. (2016) 5:e002993. doi: 10.1161/JAHA.115.002993

9. Curci JA, Liao S, Huffman MD, Shapiro SD, Thompson RW. Expression and localization of macrophage elastase (matrix metalloproteinase-12) in abdominal aortic aneurysms. J Clin Invest. (1998) 102:1900-10. doi: 10.1172/JCI2182

10. Koch AE, Haines GK, Rizzo RJ, Radosevich JA, Pope RM, Robinson PG, et al. Human abdominal aortic aneurysms. Immunophenotypic analysis suggesting an immune-mediated response. Am J Pathol. (1990) 137:1199-213.

11. Tsuruda T, Kato J, Hatakeyama K, Kojima K, Yano M, Yano Y, et al. Adventitial mast cells contribute to pathogenesis in the progression of abdominal aortic aneurysm. Circ Res. (2008) 102:1368-77. doi: 10.1161/CIRCRESAHA.108.173682

12. Ocana E, Bohorquez JC, Perez-Requena J, Brieva JA, Rodriguez C. Characterisation of $\mathrm{T}$ and $\mathrm{B}$ lymphocytes infiltrating abdominal aortic aneurysms. Atherosclerosis. (2003) 170:39-48. doi: 10.1016/S0021-9150(03)00282-X

13. Anidjar S, Dobrin PB, Eichorst M, Graham GP, Chejfec G. Correlation of inflammatory infiltrate with the enlargement of experimental aortic aneurysms. J Vasc Surg. (1992) 16:139-47. doi: 10.1016/0741-5214(92)90101-D

14. Reeps C, Pelisek J, Seidl S, Schuster T, Zimmermann A, Kuehnl A, et al. Inflammatory infiltrates and neovessels are relevant sources of and $1079 / 1 / \mathrm{MOB} / 13 / 2014 / 0$ to $\mathrm{AS}$ and $1280 / \mathrm{MOB} / \mathrm{IV} / 2015 / 0$ to TM); the European Research Council (Project Identifier: 726318); and the British Heart Foundation grant RE/13/5/30177. NM was supported by the Engineering and Physical Sciences Research Council (EPSRC) grant EP/L014165/1.

\section{SUPPLEMENTARY MATERIAL}

The Supplementary Material for this article can be found online at: https://www.frontiersin.org/articles/10.3389/fimmu. 2019.01979/full\#supplementary-material

MMPs in abdominal aortic aneurysm wall. Pathobiology. (2009) 76:243-52. doi: 10.1159/000228900

15. Blomkalns AL, Gavrila D, Thomas M, Neltner BS, Blanco VM, Benjamin SB, et al. CD14 directs adventitial macrophage precursor recruitment: role in early abdominal aortic aneurysm formation. J Am Heart Assoc. (2013) 2:e000065. doi: 10.1161/JAHA.112.000065

16. Boytard L, Spear R, Chinetti-Gbaguidi G, Acosta-Martin AE, Vanhoutte J, Lamblin $\mathrm{N}$, et al. Role of proinflammatory CD68(+) mannose receptor(-) macrophages in peroxiredoxin-1 expression and in abdominal aortic aneurysms in humans. Arterioscler Thromb Vasc Biol. (2013) 33:431-8. doi: 10.1161/ATVBAHA.112.300663

17. Daugherty A, Rateri DL, Charo IF, Owens AP, Howatt DA, Cassis LA. Angiotensin II infusion promotes ascending aortic aneurysms: attenuation by CCR2 deficiency in apoE-/- mice. Clin Sci. (2010) 118:681-9. doi: 10.1042/CS20090372

18. Dutertre CA, Clement M, Morvan M, Schakel K, Castier Y, Alsac $\mathrm{JM}$, et al. Deciphering the stromal and hematopoietic cell network of the adventitia from non-aneurysmal and aneurysmal human aorta. PLoS ONE. (2014) 9:e89983. doi: 10.1371/journal.pone. 0089983

19. Ghigliotti G, Barisione C, Garibaldi S, Brunelli C, Palmieri D, Spinella G, et al. CD16(+) monocyte subsets are increased in large abdominal aortic aneurysms and are differentially related with circulating and cell-associated biochemical and inflammatory biomarkers. Dis Markers. (2013) 34:131-42. doi: $10.1155 / 2013 / 836849$

20. Owens AP III, Rateri DL, Howatt DA, Moore KJ, Tobias PS, Curtiss LK, et al. MyD88 deficiency attenuates angiotensin II-induced abdominal aortic aneurysm formation independent of signaling through Toll-like receptors 2 and 4. Arterioscler Thromb Vasc Biol. (2011) 31:2813-9. doi: 10.1161/ATVBAHA.111.238642

21. Xiong W, Knispel R, MacTaggart J, Greiner TC, Weiss SJ, Baxter BT. Membrane-type 1 matrix metalloproteinase regulates macrophage-dependent elastolytic activity and aneurysm formation in vivo. J Biol Chem. (2009) 284:1765-71. doi: 10.1074/jbc.M806239200

22. Forester ND, Cruickshank SM, Scott DJ, Carding SR. Functional characterization of $\mathrm{T}$ cells in abdominal aortic aneurysms. Immunology. (2005) 115:262-70. doi: 10.1111/j.1365-2567.2005.02157.x

23. Galle C, Schandene L, Stordeur P, Peignois Y, Ferreira J, Wautrecht JC, et al. Predominance of type $1 \mathrm{CD} 4+\mathrm{T}$ cells in human abdominal aortic aneurysm. Clin Exp Immunol. (2005) 142:519-27. doi: 10.1111/j.1365-2249.2005.02938.x

24. Duftner C, Seiler R, Klein-Weigel P, Gobel H, Goldberger C, Ihling C, et al. High prevalence of circulating CD4+CD28- T cells in patients with small abdominal aortic aneurysms. Arterioscler Thromb Vasc Biol. (2005) 25:134752. doi: 10.1161/01.ATV.0000167520.41436.c0

25. Tang PC, Yakimov AO, Teesdale MA, Coady MA, Dardik A, Elefteriades $\mathrm{JA}$, et al. Transmural inflammation by interferon-gamma-producing $\mathrm{T}$ cells correlates with outward vascular remodeling and intimal expansion of ascending thoracic aortic aneurysms. FASEB J. (2005) 19:1528-30. doi: 10.1096/fj.05-3671fje

26. Schonbeck U, Sukhova GK, Gerdes N, Libby P. T(H)2 predominant immune responses prevail in human abdominal aortic aneurysm. Am J Pathol. (2002) 161:499-506. doi: 10.1016/S0002-9440(10) 64206-X 
27. Zhou HF, Yan H, Cannon JL, Springer LE, Green JM, Pham CT. CD43-mediated IFN-gamma production by $\mathrm{CD} 8+\mathrm{T}$ cells promotes abdominal aortic aneurysm in mice. J Immunol. (2013) 190:5078-85. doi: 10.4049/jimmunol.1203228

28. Lindeman JH, Abdul-Hussien H, van Bockel JH, Wolterbeek R, Kleemann R. Clinical trial of doxycycline for matrix metalloproteinase-9 inhibition in patients with an abdominal aneurysm: doxycycline selectively depletes aortic wall neutrophils and cytotoxic T cells. Circulation. (2009) 119:2209-16. doi: 10.1161/CIRCULATIONAHA.108.806505

29. Shimizu K, Shichiri M, Libby P, Lee RT, Mitchell RN. Th2-predominant inflammation and blockade of IFN-gamma signaling induce aneurysms in allografted aortas. J Clin Invest. (2004) 114:300-8. doi: 10.1172/JCI19855

30. Xiong W, Zhao Y, Prall A, Greiner TC, Baxter BT. Key roles of CD4+ $\mathrm{T}$ cells and IFN-gamma in the development of abdominal aortic aneurysms in a murine model. J Immunol. (2004) 172:2607-12. doi: 10.4049/jimmunol.172.4.2607

31. Badimon L, Cubedo J. Adipose tissue depots and inflammation: effects on plasticity and resident mesenchymal stem cell function. Cardiovasc Res. (2017) 113:1064-73. doi: 10.1093/cvr/cvx096

32. Guzik TJ, Skiba DS, Touyz RM, Harrison DG. The role of infiltrating immune cells in dysfunctional adipose tissue. Cardiovasc Res. (2017) 113:1009-23. doi: $10.1093 / \mathrm{cvr} / \mathrm{cvx} 108$

33. Oikonomou EK, Marwan M, Desai MY, Mancio J, Alashi A, Hutt Centeno E, et al. Non-invasive detection of coronary inflammation using computed tomography and prediction of residual cardiovascular risk (the CRISP CT study): a post-hoc analysis of prospective outcome data. Lancet. (2018) 392:929-39. doi: 10.1016/S0140-6736(18)31114-0

34. Guzik TJ, Mangalat D, Korbut R. Adipocytokines - novel link between inflammation and vascular function? J Physiol Pharmacol. (2006) 57:505-28.

35. Guzik TJ, Marvar PJ, Czesnikiewicz-Guzik M, Korbut R. Perivascular adipose tissue as a messenger of the brain-vessel axis: role in vascular inflammation and dysfunction. J Physiol Pharmacol. (2007) 58:591-610.

36. Akoumianakis I, Antoniades C. The interplay between adipose tissue and the cardiovascular system: is fat always bad? Cardiovasc Res. (2017) 113:999-1008. doi: $10.1093 / \mathrm{cvr} / \mathrm{cvx} 111$

37. Sorop O, Olver TD, van de Wouw J, Heinonen I, van Duin RW, Duncker DJ, et al. The microcirculation: a key player in obesity-associated cardiovascular disease. Cardiovasc Res. (2017) 113:1035-45. doi: 10.1093/cvr/cvx093

38. Folkesson M, Vorkapic E, Gulbins E, Japtok L, Kleuser B, Welander M, et al. Inflammatory cells, ceramides, and expression of proteases in perivascular adipose tissue adjacent to human abdominal aortic aneurysms. J Vasc Surg. (2017) 65:1171-1179.el. doi: 10.1016/j.jvs.2015.12.056

39. Piepoli MF, Hoes AW, Agewall S, Albus C, Brotons C, Catapano AL, et al. 2016 European Guidelines on cardiovascular disease prevention in clinical practice: the sixth joint task force of the European society of cardiology and other societies on cardiovascular disease prevention in clinical practice (constituted by representatives of 10 societies and by invited experts)developed with the special contribution of the European Association for Cardiovascular Prevention \& Rehabilitation (EACPR). Eur Heart J. (2016) 37:2315-81. doi: 10.1093/eurheartj/ehw106

40. Bhatta A, Yao L, Xu Z, Toque HA, Chen J, Atawia RT, et al. Obesity-induced vascular dysfunction and arterial stiffening requires endothelial cell arginase 1. Cardiovasc Res. (2017) 113:1664-76. doi: 10.1093/cvr/cvx164

41. Jia G, Aroor AR, Sowers JR. The role of mineralocorticoid receptor signaling in the cross-talk between adipose tissue and the vascular wall. Cardiovasc Res. (2017) 113:1055-63. doi: 10.1093/cvr/cvx097

42. Sun XQ, Abbate A, Bogaard HJ. Role of cardiac inflammation in right ventricular failure. Cardiovasc Res. (2017) 113:1441-52. doi: $10.1093 / \mathrm{cvr} / \mathrm{cvx} 159$

43. Thakore P, Brain SD. The role of perivascular adipose tissue-derived sensory nerves in influencing vascular regulation. Cardiovasc Res. (2017) 113:847-8. doi: $10.1093 / \mathrm{cvr} / \mathrm{cvx} 099$
44. Maga P, Mikolajczyk TP, Partyka L, Siedlinski M, Maga M, Krzanowski M, et al. Involvement of CD8+ T cell subsets in early response to vascular injury in patients with peripheral artery disease in vivo. Clin Immunol. (2018) 194:26-33. doi: 10.1016/j.clim.2018.06.006

45. Sagan A, Mrowiecki W, Mikolajczyk TP, Urbanski K, Siedlinski M, Nosalski $\mathrm{R}$, et al. Local inflammation is associated with aortic thrombus formation in abdominal aortic aneurysms. Relationship to clinical risk factors. Thromb Haemost. (2012) 108:812-23. doi: 10.1160/TH12-05-0339

46. Henrichot E, Juge-Aubry CE, Pernin A, Pache JC, Velebit V, Dayer JM, et al. Production of chemokines by perivascular adipose tissue: a role in the pathogenesis of atherosclerosis? Arterioscler Thromb Vasc Biol. (2005) 25:2594-9. doi: 10.1161/01.ATV.0000188508.40052.35

47. Guzik TJ, Hoch NE, Brown KA, McCann LA, Rahman A, Dikalov S, et al. Role of the $\mathrm{T}$ cell in the genesis of angiotensin II induced hypertension and vascular dysfunction. J Exp Med. (2007) 204:2449-60. doi: 10.1084/jem.20070657

48. Teo FH, de Oliveira RTD, Villarejos L, Mamoni RL, Altemani A, Menezes $\mathrm{FH}$, et al. Characterization of $\mathrm{CD} 4(+) \mathrm{T}$ cell subsets in patients with abdominal aortic aneurysms. Mediators Inflamm. (2018) 2018:6967310. doi: $10.1155 / 2018 / 6967310$

49. MacRitchie N, Grassia G, Noonan J, Cole JE, Hughes CE, Schroeder J, et al. The aorta can act as a site of naive CD4+ T cell priming. Cardiovasc Res. (2019) cvz102. doi: 10.1093/cvr/cvz102. [Epub ahead of print].

50. Mikolajczyk TP, Nosalski R, Szczepaniak P, Budzyn K, Osmenda G, Skiba $\mathrm{D}$, et al. Role of chemokine RANTES in the regulation of perivascular inflammation, T cell accumulation, and vascular dysfunction in hypertension. FASEB J. (2016) 30:1987-99. doi: 10.1096/fj.201500088R

51. Ait-Oufella H, Wang Y, Herbin O, Bourcier S, Potteaux S, Joffre J, et al. Natural regulatory $\mathrm{T}$ cells limit angiotensin II-induced aneurysm formation and rupture in mice. Arterioscler Thromb Vasc Biol. (2013) 33:2374-9. doi: 10.1161/ATVBAHA.113.301280

52. Giraud A, Zeboudj L, Vandestienne M, Joffre J, Esposito B, Potteaux S, et al. Gingival fibroblasts protect against experimental abdominal aortic aneurysm development and rupture through tissue inhibitor of metalloproteinase-1 production. Cardiovasc Res. (2017) 113:1364-75. doi: 10.1093/cvr/cvx110

53. Zhou Y, Wu W, Lindholt JS, Sukhova GK, Libby P, Yu X, et al. Regulatory $\mathrm{T}$ cells in human and angiotensin II-induced mouse abdominal aortic aneurysms. Cardiovasc Res. (2015) 107:98-107. doi: 10.1093/cvr/cvv119

54. Dale MA, Ruhlman MK, Baxter BT. Inflammatory cell phenotypes in AAAs: their role and potential as targets for therapy. Arterioscler Thromb Vasc Biol. (2015) 35:1746-55. doi: 10.1161/ATVBAHA.115.305269

55. Clement M, Guedj K, Andreata F, Morvan M, Bey L, Khallou-Laschet $\mathrm{J}$, et al. Control of the $\mathrm{T}$ follicular helpergerminal center $\mathrm{B}$-cell axis by $\mathrm{CD} 8(+)$ regulatory $\mathrm{T}$ cells limits atherosclerosis and tertiary lymphoid organ development. Circulation. (2015) 131:560-70. doi: 10.1161/CIRCULATIONAHA.114.0 10988

56. Hughes CE, Benson RA, Bedaj M, Maffia P. Antigen-presenting cells and antigen presentation in tertiary lymphoid organs. Front Immunol. (2016) 7:481. doi: 10.3389/fimmu.2016.00481

Conflict of Interest Statement: The authors declare that the research was conducted in the absence of any commercial or financial relationships that could be construed as a potential conflict of interest.

Copyright (c) 2019 Sagan, Mikolajczyk, Mrowiecki, MacRitchie, Daly, Meldrum, Migliarino, Delles, Urbanski, Filip, Kapelak, Maffia, Touyz and Guzik. This is an open-access article distributed under the terms of the Creative Commons Attribution License (CC BY). The use, distribution or reproduction in other forums is permitted, provided the original author(s) and the copyright owner(s) are credited and that the original publication in this journal is cited, in accordance with accepted academic practice. No use, distribution or reproduction is permitted which does not comply with these terms. 